certificates that the statements accurately represent the evidence of the witness/expert.

- It should be a rule of court that no expert or other witness is permitted to be paid on a speculative, contingent or conditional fee basis. A code of guidance will not suffice.

- Any undertaking which impairs the ability of members of the public to gain access to a particular solicitor or solicitors should be submitted to the court for the court's approval at the cost of the party seeking the undertaking. Rules of court governing such applications should emphasise the potential detrimental effect on access to justice and the court's obligations under Article 6 of the ECHR.

- The Law Society's Practice Rules should make clear that a solicitor's duty to their client under Practice Rule 1 puts the solicitor in a situation of conflict with their client if the solicitor is aware that insurance they advise the client to take out is either unnecessary or unnecessarily expensive.

- There should be written into the Bar's Code of Conduct stronger provisions requiring barristers always to act in accordance with their client's interest, and not the personal interests of the barristers. These provisions should be carefully drafted so that they can be used as the basis for charges of professional misconduct if evidence that they have not been complied with is forthcoming.
- Intra-chambers conflict problems should be covered by specific provisions in the Bar's Code of Conduct, and not be left merely to the Ethical Guidance provided by the Bar Council.

- Judges should play their appropriate part in maintaining and raising ethical standards in the legal professions. (c)

The working party members were: Geoffrey Bindman, senior partner, Bindman \& Partners; Ben Emmerson QC; Max Findlay, legal writer \& journalist; Matthias Kilian, Senior Research Fellow, Institute of Employment \& Business Law, Cologne; Jennifer Levin, Foundation professor of Law, University of Wales; The Hon Mr Justice Lightman; David Mackie QC; Bill Montague, partner, Dexter Montague \& Partners; Richard Moorhead, Senior Research Fellow, IALS;

Richard O'Dair, senior lecturer in law, University College, London; Andrew Phillips, partner, Bates Wells \& Braithwaite; Professor Avrom Sherr, Woolf Professor of Legal Education, IALS; Dr Hilary Sommerlad, solicitor, senior lecturer in law, Leeds Metropolitan University; Richard Southwell QC; Stella Yarrow, Research Fellow, School of Law, University of Westminster.

Copies of the Society for Advanced Legal Studies Report on The Ethics of Conditional Fees can be obtained, price $£ 30$ ( 220 for SALS members) from Tracy Paradise, Secretary of SALS, on 02078625866.

\title{
Midnight in the garden of the CFA people
}

by Richard Moorhead and Avrom Sherr

$\mathrm{T}$ There is a lot riding on the success of conditional fee agreements (CFAs). They are a central plank in the government's legal services policy and, for many in the profession they offer the opportunity to reclaim practices damaged by the erosion and removal of legal aid. The Law Society has endorsed a conditional fee agreement referral scheme backed by insurance and there are numerous insurance companies selling conditional fee agreement related policies. More fundamentally, conditional fee agreements currently represent the best hope for the general public of gaining access to justice. Little surprise then that a report, produced by a working group of the Society of Advanced Legal Studies (SALS), The Ethics of Conditional Fee Arrangements, should provoke a strong reaction from conditional fee agreement lawyers (see 'Conditional Fee Agreements', New Law Journal, 9 February 2001).

All fee arrangements can lead to conflicts of interest, and these problems must be kept in mind in assessing the pros and cons of conditional fee agreements. Similarly, the working party was well aware of the changes introduced by the Access to Justice Act 1999; changes fully described in Chapter 2 of the report, which seek to reduce the exposure of clients to costs risks inherent in CFAs. It is understandable that government and some practitioners, with so much invested in the success of the scheme, would claim that the Access to Justice Act 1999 provides an answer to all of the problems raised by conditional fee 
agreements. Unfortunately, whilst conditional fee agreements should open up access to justice for some clients, it is clear that conditional fee agreements raise ethical and consumer protection issues, quite apart from the sustainability, desirability and cost of having a justice system in symbiotic union with the insurance industry.

A principal problem with conditional fee agreements is the mismatch of the rhetoric of 'no win no fee' and the claim that, 'the public love CFAs because they take the risk away from the public and put it on solicitors, where it belongs'. The truth is that these agreements are enormously complex, and at times loaded against the interests of the clients. Research indicates how difficult these complexities are for clients (see S Yarrow and P Abrams, 'Nothing to lose: clients' experience of using conditional fees'). Indeed for clients, Giles Smith's description of real tennis may be apt, particularly when things go wrong: 'imagine a squash match set in an abattoir with rules drawn up by Anthony Burgess' and you might not go far wrong (see G Smith, 'Midnight in the Garden of Evel Knievel').

The 'no win no fee' rhetoric, and the claim that all the risk falls on the lawyer, can be judged initially by looking at the definition of 'win'. The Law Society's standard conditional fee agreement defines a 'win' as: 'Your claim for damages is finally decided in your favour, whether by a court decision or an agreement to pay you damages'. Win does not mean the payment of damages. So clients need to understand that if damages are not recovered, they have still 'won' and a fee is payable. As a result, clients, not lawyers, bear the risk of non-recovery of a damages agreement/award. It would be a simple matter to make the definition of 'wins' accord with what clients think it means and conditional fee agreements would become less complex. For that reason, the report recommended that for conditional fee agreements aimed wholly or mainly at recovering damages for the client, 'success' should be defined in terms of damages recovered rather than damages awarded, with provisions for solicitors to derogate from this approach where they can demonstrate fully-informed consent from the client (to assume the risk of nonrecovery).

There are other areas where the simple appeal of 'no win no fee' masks its complexities from clients. Where a client wants to pull out of a conditional fee agreement case they do not 'win', yet they are liable for a fee. Similarly, the notion of 'fee' is confined only to the claimant lawyer's profit costs, a distinction which needs to be made absolutely clear to clients who will not immediately understand what it means when they are told they can be asked to pay for disbursements and unrecovered insurance premiums. The working party did not think that lawyers should be prevented from charging clients in these circumstances, but suggested that this be dealt with by giving clients a short 'cooling-off period' to think about the implications of the conditional fee agreement (particularly as pulling out of a conditional fee agreement is likely to be difficult) and the production of a video to explain the intricacies of conditional fee agreements in a palatable form.

A final area, which needs some examination, is the role of cost caps in conditional fee agreements. One of the myths surrounding the Access to Justice Act is that it now protects clients from paying their own lawyers for success fees, which are not recoverable from the opposition. This is not true. Success fees are split into two parts: the part based on risk (which should only be recoverable from the opposition) and the part based on the cost of borrowing. Lawyers can only recover this bit of the success fee from clients (and from their damages). Early indications are that the most scrupulous lawyers will either not claim any cost of borrowing uplift or will only claim a minor sum. About others, or less profitable firms, we can be less sure. Defendant lawyers (and their insurer clients) are itching to reduce the amounts that claimant lawyers receive under conditional fee agreement success fees. If they succeed, even in part, there is a real concern that some lawyers will cover themselves by claiming increasing amounts under the cost-of-borrowing element of a success fee. This type of success fee is not only applicable in 'very limited circumstances'; it is possible in every single conditional fee agreement case. This is one of the areas where there is almost no protection for the client, and is one reason why the working party recommended a cap on the total costs recovered from the client's damages. Similarly, the report addresses the question of a cap on costs breaching the indemnity principle: the report's proposals on a cap are contingent on abolition of the indemnity principle.

Proponents of conditional fee agreements have a good case on the need for conditional fee agreements (or something like them) to protect access to justice in the absence of legal aid, but conditional fee agreements and the Access to Justice Act have not yet struck a deal which is genuinely in the interests of the consumer or which will promote the good repute of the profession. It will be a shame if the loopholes and snags in the conditional fee agreement scheme begin to loom larger in the public consciousness when more members of the general public are caught out. These problems need to be dealt with quickly to prevent lawyers, conditional fee agreements, and the justice system, being tinged with disrepute.

This article was first published in the 23 February issue of the New Law Journal. (c)

Richard Moorhead
Senior Research Fellow, Institute of Advanced Legal Studies, and Convenor of
the SALS Working Party Report on the Ethics of Conditional Fee
Arrangements.
Avrom Sherr
Woolf Professor of Legal Education, Institute of Advanced Legal Studies, and
a member of the Working Party.

